\title{
Working Together Within The University: An Interdisciplinary Project In Education
}

\author{
Isabel-María Ferrándiz-Vindel, University of Castilla-La Mancha, Spain
}

\begin{abstract}
The evolution of the professional and environmental conditions is forcing the university education to a change in the teaching-learning process. This implies a new definition in the roles and functions of university teachers from whom new ways of educational training should arise. These days, university teachers are called upon to encourage and facilitate their students' learning. This new role of the teacher should be to help put the University at the level of the requirements and possibilities of this era, and those to come as well. In order to make the innovation and the change real in higher education is essential to start from concepts like "cooperation and collaboration" within the teaching staff, between them and in their departments. According to the new use of the didactic and organizational planning in higher education, this aspect is an aim for the development of the teaching quality in universities. In higher education, there is an increasing need of a formation which not only increases the conceptual knowledge of the professionals but also provides them the instrumental and attitudinal resources required for the professional development of their tasks. The aim of this paper is to show the work which has been done by a group of teachers at the Faculty of Educational Sciences and Humanities during four years in the degree of Educational Psychology. The activities carried out (information stands, sensitization workshops, leaflets with scientific-technical information, among others) facilitate our students' apprehension of the basic elements of different subject matters and increase their skills of analyzing, contrasting, synthesizing, increasing knowledge, debating, etc. and, in addition, they can confront the need to give an answer - as a professional- to very different situations taken from the real world.
\end{abstract}

Keywords: Teaching Coordination; Innovation; Teaching methods

\section{INTRODUCTION}

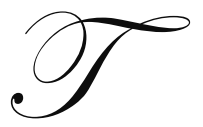

he European Higher Education Area (EHEA), represents a real pedagogical conversion. Aside from all the Management and administrative changes involved in the process which are a challenge for the university institution (degree structure and the definition of academic credits and accreditation system of education), underlies the most important change, the one that has to take place in the classroom, in the teaching-learning process, where the chief architects of this change must be the teacher and the learner.

Building this new European area raises a renewing concern for college teaching. In this sense, and following Hernandéz de la Torre, (2006) the objectives which must be resolved by Higher Education in the near future are:

- $\quad$ Training responsible and committed citizens

- $\quad$ Supplying the professionals required by society

- $\quad$ Developing scientific research

- $\quad$ Preserving and transmitting culture

- $\quad$ Building the vanguard of intellectual and moral solidarity.

These first changes are structural and organizational (e.g. ECTS) but they must also be of a behavioural and personal nature (e.g. attitude changes in the subject and ways of creating knowledge). Both changes should be seen 
to at the same time, mainly, because structural changes are affecting the way we interact and our job performance at work and these are highly dependent on the attitude we adopt. (Cebrian de la Serna, M., 2008) Structural changes do not allow us to remain there, in exclusive formal changes, there is no: "lets change the wrapper and continue doing the same". This seems unlikely to happen without leaving us perplexed.

We should understand that we have to think in terms of "learning institutions" more so, if we also want teachers to consider their work as an opportunity to learn during the change, and at the same time, this may reflect on their students self-learning.

\section{THE COLLEGE PROFESSOR}

Knowing how teachers should organize content so they can teach it, along with the development of tutorial functions, bring us to think that the planning of development in the curricula, when coordinated with professors of the same Department, optimizes the role of teachers and improves student learning.

For some time University professors have realized the importance of this function exercised in collaboration with colleagues, this way Mateo (1990) pointed out that among the most important duties performed by the college professor there are three dimensions: the teaching function, the research function and the management function, which are organized as follows:

- Teaching organization: student distribution, assignment of teachers, dedication to teaching, management.

- $\quad$ Programming: objectives, content, resources.

- $\quad$ Teaching evaluation: class development, teaching methods, evaluation system, classroom climate.

- Academic activities outside the classroom: coordinating with other teachers, in-class teaching activities, out of class activities, student tutoring, information and help services, and research.

Before, the school was the teacher as means of dissemination; contents were the epistemological structure to follow and the classroom and office the only communication space. Nowadays we have focused teaching in competences, virtual and real classrooms are shared, and what is proving to be more difficult: more and more the teacher has to assume the role of "facilitator" and "promoter" of self-teaching in students. (Cebrián de la Serna, M., 2008)

As we can see, the college professor must become involved, in teaching, in the Department's university life and assume the role of researcher, as well as coordinating with other professors for the developing teaching functions.

Rodríguez $(2002,191)$ clarifies a number of competencies which college professors will have to develop in order to perform their work and these will have to turn into skills to adapt to a technical and industrial society. Among them he highlights the following:

- $\quad$ Management of basic academic skills.

- $\quad$ Acquiring work habits

- $\quad$ Developing significant work values

- $\quad$ Knowledge of the company and work

- $\quad$ Information about training and job opportunities

- $\quad$ Skill in making decisions related to the degree

- Job search resources

- $\quad$ Use of leisure and free time

- $\quad$ Ability to humanize the workplace

All these competencies are trying to make clear that one of the features which teachers must currently develop is that of working in collaboration to propitiate in students a number of capabilities related to work habits by both teachers of the same teaching Department and later on students at their workplace. The purpose of it all is to 
create a change in the way University teaching is conceived, trying to make the learning collective design and collaborative work the main objectives. (Benito y Cruz, 2005).

For the faculty, in general, this change could mean the introduction of new teaching methodologies to promote the active involvement of students in their learning processes. (Sánchez Moreno, 2008) But beyond the changes which might take place in the classroom, this innovation must be nourished by a previous work of reflection and planning of the classes that the teacher traditionally performs in an individual manner.

\section{INTERDISCIPLINARY PROJECT AT UNIVERSITY}

Today's society demands enterprising college graduates, with initiative, creative, independent, critical and reflective, but at the same time capable of working collaboratively, flexible and responsible. This means a Higher Education far from the traditional teaching dogma and focussing the educational training process on the students themselves. It also means searching and testing new teaching methods making the student the protagonist of the teaching-learning process, expecting greater participation, involvement and compromise of them in the educational training process.

Our proposal responds to the idea pointed out by the 'Commission for the renovation of educational methodologies at the university" in its 2006 report:

.... Just like in any process of change in an educational organization, the key element which determines success or failure is the degree of identification and compromise of teachers with the principles and objectives stated. Members of the education community must get involved in a collective effort to make the most of the work done by each teacher individually..."

This is an interdisciplinary teaching project, where cooperative work strategies among teachers are put in place and geared towards improving their teaching; and also an active method, where students are the true protagonists of their learning.

For four years, teachers of various areas of the Educational Psychology degree (Facultad de Ciencias de la Educacion y Humanidades) at the University of Castilla la Mancha (Cuenca campus), we celebrate "Diversity Week" which links training and work setting.

We built this training project on a number of premises:

a) Meeting the needs of each of the students involved

b) Enhancing training in the work context:

- Contacting and visiting associations, schools and organizations dedicated to a particular theme related to diversity;

- Searching for bibliographic material, graphic and audiovisual web;

- Interviews with professionals who will work in these schools, etc.

c) Proposing a flexible structure combining different types of activities (attendance, non-attendance) linked to the traditional idea of a seminar or linked to a workshop and activities which could be done in teams depending on their own interests and demands; individual and group activities, activities with different methodologies as well as different practice analysis strategies.

d) Requiring participants to become the true protagonists of their own learning for which we designed a highly autonomous program.

e) Requesting voluntary participation, giving full freedom to form work groups.

\section{PEDAGOGICAL IMPLICATIONS}

This project has required focussing the educational training on learning and not teaching. These are some of the implications of this change in a pedagogical context: 


\section{Innovative" resolutions of the project}

- $\quad$ Promoting the development of creativity, initiative and the ability to make decisions

- Integrating theory and reality, manual and intellectual work

- $\quad$ Promoting changes in what people know and the use they can make of what they know

- $\quad$ Promoting the autonomy of an individual

\section{Study subjects/learning units}

- $\quad$ Contents in reference to conditions operating in reality related to Diversity.

- $\quad$ Study programs and more flexible and diversified learning processes.

- $\quad$ Elements of competence: theoretical knowledge, practical/technical, methodological and social knowledge.

- $\quad$ Attributes of competence, skills, background, aptitudes, attitudes and values.

- $\quad$ Programs articulate in reference to identified issues, to generic or specific competences, as well as the units of competence where it is detached.

- Designing learning experiences which allow us to reach different solutions or to several ways to solve problems.

- $\quad$ Creating cooperative, collaborative and supportive environments

- Alternating moments of confrontation between real situations and moments of systematization of knowledge or theory

- $\quad$ Prioritizing teaching strategies play an active role, allowing them to build and discover knowledge by themselves

\section{Learning}

- $\quad$ Diversifies learning possibilities

- Acknowledges work as a resource to consolidate what we know, to put what we know into practice and learn more

- $\quad$ Acknowledges individuals as being able to self-direct an organize their learning

- Acknowledges different ways of learning and therefore, the fact that classrooms are not the only place to learn

- What is learned (generic and specific competences) must be applied to different problems and situations (transferability)

- $\quad$ Requires active and reflective processes

\section{Evaluation}

- $\quad$ Competency units are broken down into performance indicators or criteria. Performance indicators or criteria refer back to the evaluation criteria

- $\quad$ Assessment practices are modified, making them more consistent with the work being done

- Performing longitudinal and multiple assessments to gather performance evidence from different sources

Assuming this responsibility has involved that both the educational institution and most of all, the teaching staff, have consistently promoted actions in the pedagogical and didactic fields. In this project the role of the teacher has been essential, as a designer of learning areas and experiences for the student. The faculty have continuously participated in education and training actions which have allowed them to develop similar competencies to those we are trying to shape the students with.

This has been a positive experience for the student body because of, the mere fact of placing themselves behind one of the stands we made, being able to organize, prepare and plan this sessions coordinating different themes chosen by them, has made them aware of their own learning (management of basic academic skills, acquiring work habits), the need for collaboration, involvement and compromise as key elements to build a professional culture (in this case, educational Psychology) and above all accepting the idea of the group as a basic unit of change and as an area for educational training (initially and permanently) 


\section{AUTHOR INFORMATION}

Isabel María Ferrándiz Vindel: PhD in Pedagogy by Complutense University of Madrid (UCM), Spain. Professor in the Department of Education. Interested in inclusive education of disabled people and/or reduced mobility in all educational levels and the training of those professionals who will teach them. E-mail: isabel.ferrandiz@uclm.es.

\section{REFERENCES}

1. Benito, A., y Cruz, A., (2002) Nuevas claves para la docencia universitaria en el espacio europeo de educación superior. Madrid: Narcea S.A. ediciones

2. Cebrián de la Serna, M., (2008) "Los procesos de innovación didáctica en el marco del Espacio Europeo de Educación Superior (EEES)", en Rodríguez Escanciano, I., (coord.) El nuevo perfil del profesor universitario en el EEES: claves para la renovación metodológica. Valladolid: Universidad Europea Miguel de Cervantes. 19-36

3. Comisión para la renovación de las metodologías educativas en la Universidad (2006) Propuestas para la renovación de las metodologías educativas en la universidad. M.E.C.: Secretaría de Estado de Universidades

4. Hernández de la Torre, E., (2006) "La coordinación entre profesores en los departamentos universitarios para la mejora de la función tutorial". XXI Revista de Educación, vol. 8, Huelva: Universidad de Huelva Publicaciones. 163-174.

5. Martín Delgado, J.M., (1989) “Reforma Universitaria: nuevas titulaciones. Situación actual”, en JIMÉNEZ, A., y LOU, M.A., (Eds.): Actas II Congreso Educación y Sociedad. Granada: Colegio Oficial de Doctores y Licenciados. 41-50.

6. Mateo, J., (1990) "Función docente y demandas discentes", Revista Española de Pedagogía, 186. 40-49.

7. Rodríguez, A., (2002) "La orientación en la Universidad: ámbitos de intervención, metas y objetivos, roles y funciones del orientador", en ÁVAREZ, V. y LÁZARO, A. (coord.) Calidad de las Universidades y Orientación Universitaria, Málaga: Aljibe. 171-194.

8. Sánchez Moreno, M., (2008) "Asesoramiento en la universidad. Poniendo a trabajar a la experiencia". Profesorado. Revista de currículum y formación del profesorado. From http://www.ugr.es/local/recfpro/rev121ART7b.pdf (accessed 19.07.2010) 
NOTES 